\title{
The Use of Plastic Waste as Transition Materials in the Production of Pavement Blocks
}

\author{
Tagbor TA*, Adjei D, Boakye AK and Annan G \\ Council for Scientific and Industrial Research-Building and Road Research Institute, Ghana
}

Submission: August 14, 2019; Published: September 13, 2019

*Corresponding author: Tagbor TA, Council for Scientific and Industrial Research-Building and Road Research Institute, UP Box 40 Kumasi, Ghana

\begin{abstract}
Many developing countries are facing a lot of challenges with management of huge quantities of solid waste generated on daily basis. Plastic waste which is part of solid waste poses a menace to sustainable development due to its slow rate of degradability and the indiscriminate way it is disposed. To lessen the negative impacts on the environment and the associated effects on human health, plastic waste is being considered as materials in transition and are being used in the production of pavement blocks and other materials for construction purposes. The study reports some physical and mechanical properties of plastic waste pavement blocks produced by one company in Ghana which has taken a major lead in the direction of adding value to plastic waste for construction. Results are compared to two other pavement block types made from cement and fired clay pavement blocks and discussed. Using plastic waste as transition materials for pavement blocks may among other benefits listed, translate to reduction in construction cost and large quantities of plastic waste polluting the environment and may contribute to cleaner cities and towns.
\end{abstract}

Keywords: Plastic waste; Transition materials; Pavement blocks; Environment; Construction

\section{Introduction}

Economic growth and changing consumption patterns are resulting in rapid increase in the use of plastics in the world. Thus, consumption of plastic material has increased from 5 million tons in the 1950 s to 100 million in the 2000s. In Ghana per capita generation of plastic waste has been reported to be between 0.0016- $0.035 \mathrm{~kg} /$ person/day. And, plastics make up between $18-20 \%$ component materials in the waste stream [1]. There are however concerns about plastic waste disposal methods commonly employed in many developing countries as they do not deal effectively with the large tonnes of plastic waste generated. These disposal methods include dumping plastic waste in landfills, incineration and open littering. Since plastics take several years to degrade, there are challenges associated with their improper disposal which include:

i. Blocking drains and choking of gutters which may contribute to floods.

ii. Release of toxic gases into the atmosphere when openly burnt. Some of these gases may be harmful to humans and cause greenhouse effects.

iii. Discarded bottles and containers may serve as breeding grounds for mosquitoes when filled with rainwater. iv. Washing of the littered plastic materials into water bodies including oceans contributing to decline of ocean life.

Common pavement materials used in Ghana include the cement pavement blocks and the fired clay pavement bricks. Portland cement imported into the country is used in the production of cement pavement blocks and is associated with increasingly high cost due the unstable value of foreign exchange. Fired claypavers produced from available local clay materials are not very popular with a lot of people because they are perceived by many as expensive. The production of fired clay pavers currently in the country relies on firewood burnt at very high temperatures. This firing method is not sustainable and associated with consumption of a lot energy. In recent times, due to the ecological and environmental challenges associated with the disposal of plastic waste, there are a lot of interest in turning plastic waste into a resource in construction. Pavement blocks produced from waste plastic and other materials like sand, quarry dust etc., is recently being promoted in many developing countries as a more affordable and a sustainable material which may be used in construction and Ghana is no exception. Though it is generally known that these plastic waste pavement blocks are strong and durable, there is little scientific data in Ghana to support this claim. This paper therefore reports a study on three types of pavement blocks produced 
from plastic waste, fired clay, and cement with regards to some of their physical and mechanical properties.

\section{Materials and Methods}

\section{Materials}

The pavements samples under study were obtained from three different commercial paving factories in Ghana. The raw materials used in the production of these pavers comprised of cement, quarry dust and fine aggregates (sand), for the cement pavers, clay for the clay pavers, and waste plastics and sand for the plastic pavers. Six samples of each paver types were randomly selected and tested for each of the various physical and mechanical properties which include density, compressive strength, flexural strength, abrasive resistance, water of absorption and durability in sea water. Plastic pavement blocks were commercially produced in bigger sizes of $30 \mathrm{~cm}$ by $30 \mathrm{~cm}$. They were cut into 4 equal part with half remaining. And test run on samples of dimension $20 \mathrm{~cm}$ by $10 \mathrm{~cm}$ with a thickness of $5 \mathrm{~cm}$. This is to make sure all types of pavement blocks have comparable sizes. Cement and fired clay pavement blocks are of hexagonal shape and with dimensions $23 \mathrm{~cm}$ by $14 \mathrm{~cm}$ with thickness $5 \mathrm{~m}$ and $20 \mathrm{~m}$ by 10.5 with thickness $6.5 \mathrm{~cm}$ respectively. The samples were cured for more than 28 days to ensure maximum mechanical strength development before the various test were conducted.

\section{Methods}

Density: The density of the various paving bricks was determined using Archimedes principle of water displacement. Dry weights of various pavers were measured and fully immersed in a tank containing water. The volume of water displaced was measured for each pavement type, and the average volume of water displaced was recorded for six samples each of the various pavers. The densities of the various pavers were determined by dividing the dry weight by the volume of water displaced [2].

Compressive strength: The compressive strength is the most prioritized property to be achieved in the production of paving bricks in almost every factory that is actively involved in manufacturing of pavers [3]. Hydraulic universal testing machine which has a maximum capacity up to $2500 \mathrm{KN}$ was used to determine the compressive of the various pavers in this study. The load was applied to the nominal area of the cement, clay and rubberized pavers to determine the various compressive strengths. The corrected compressive strength was computed using correcting factors (BIS, 2006).

Flexural strength: Flexural strength is one of the tests performed on paver blocks which serves as a quality indicator and it is considered as a basis for comparison in terms of wearing resistance. Flexural strength test was performed by subjecting the various pavers to a thwartwise force which is perpendicular to its longitudinal axis. A center line was indicated on top of the pavers which is perpendicular to its length. The pavers were supported by two support rods over a span of $150 \mathrm{~mm}$ and were tested under a central line load until failure occurred, using the INSTRON universal testing machine. The flexural strength values recorded are the average of six samples each for the various paver [4].

Water of absorption and durability in sea water: Water of absorption is the determination of the rate of absorption by measuring the increase in mass of the pavers resulting from absorption of water over a period. The pavers were fully immersed in a tank of fresh water for 24 hours and the weight measured to determine the percentage of water absorption. And, the pavements were fully immersed in a tank of sea water for four months to determine its durability by applying a load to determine the compressive strength using the universal testing machine. The percent water of absorption is determined using equation (1),

$$
\% \text { water of absorption }=\frac{\text { wet weight }- \text { dry weight }}{d r y \text { weight }} \times 100
$$

\section{Results}

\section{Density}

The density values of the various pavers are presented in Figure 1 . The values range between $1.99 \mathrm{~g} / \mathrm{cm}^{3}$ to $2.04 \mathrm{~g} / \mathrm{cm}^{3}$, with fired clay pavement block having the lowest and cement pavement block having the highest.

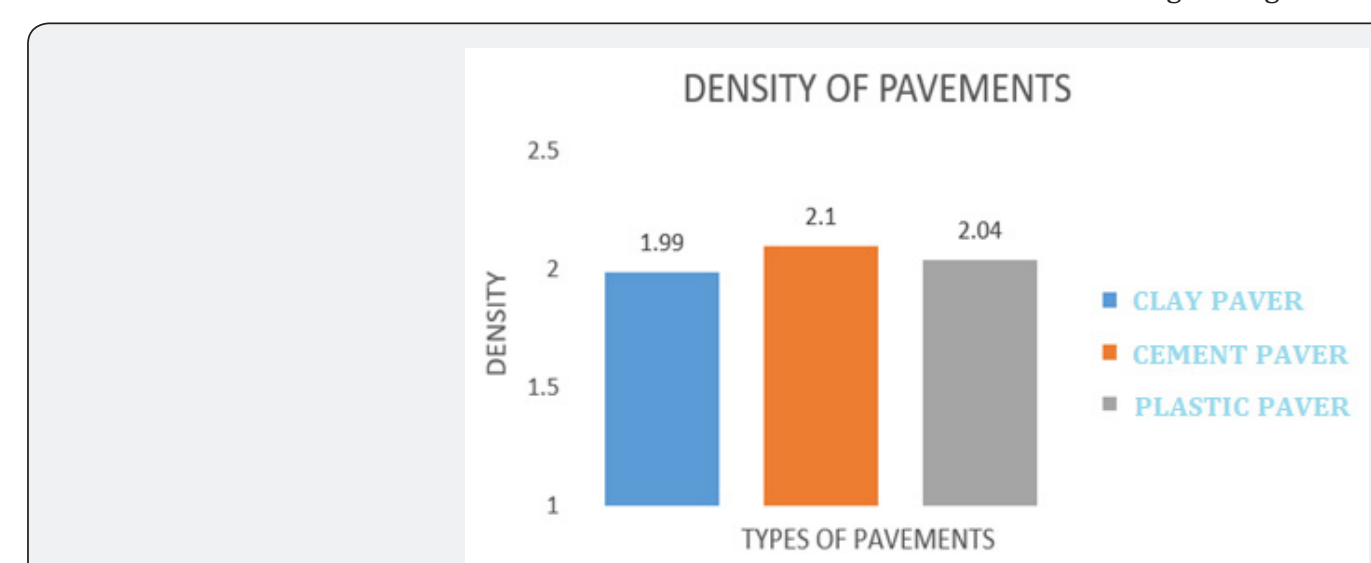

Figure 1: Average density of the three different pavers. 


\section{Civil Engineering Research Journal}

\section{Compressive Strength}

As shown in Figure 2 , fired clay pavement block recorded the highest compressive strength followed by the plastic pavement blocks with the cement pavement blocks recording the least compressive strength.

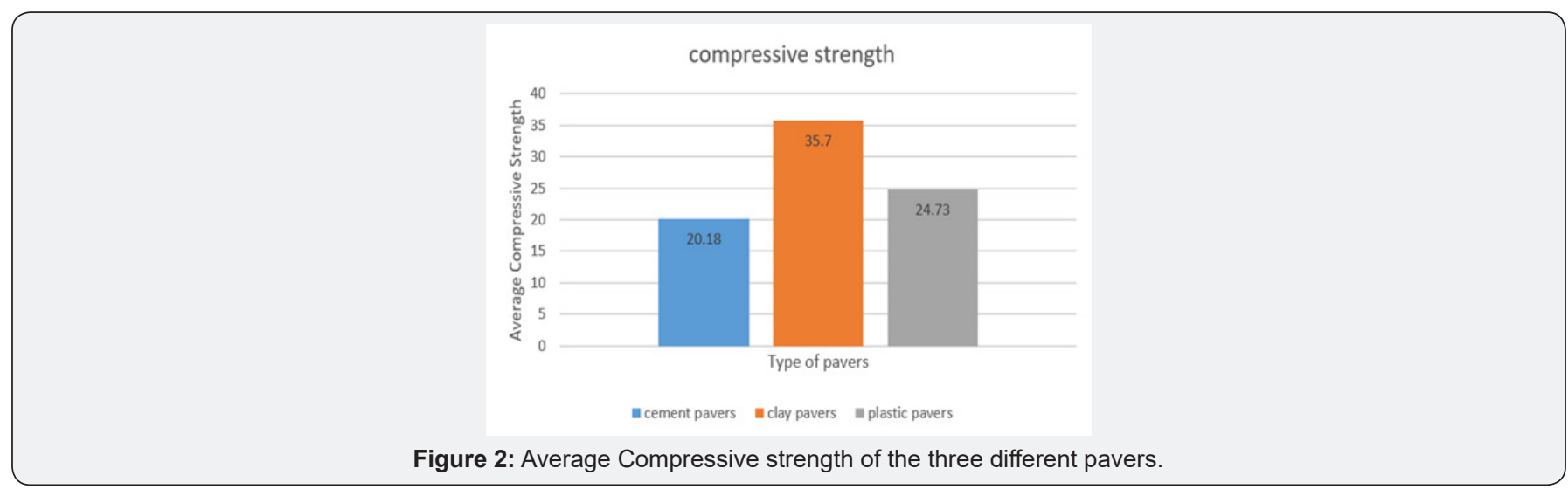

\section{Flexural Strength}

Figure 3 shows the test results of flexural strength of plastic paver, cement paver and fired clay paver to be $6.04 \mathrm{MPa}, 5.86 \mathrm{MPa}$ and 5.09MPa respectively.

\section{Water of Absorption}

Figure 4 shows the percentage water of absorption test results for fired clay, cement and plastic pavers as 11.82, 8.075 and 0.369 respectively.

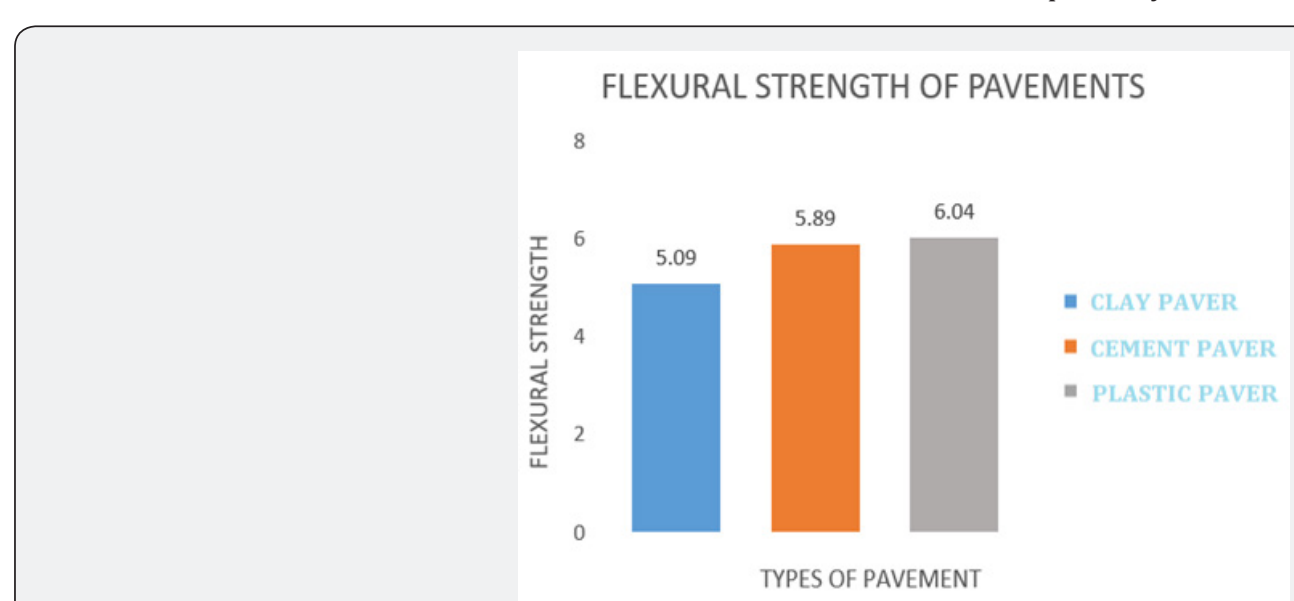

Figure 3: Average flexural strength of various pavers

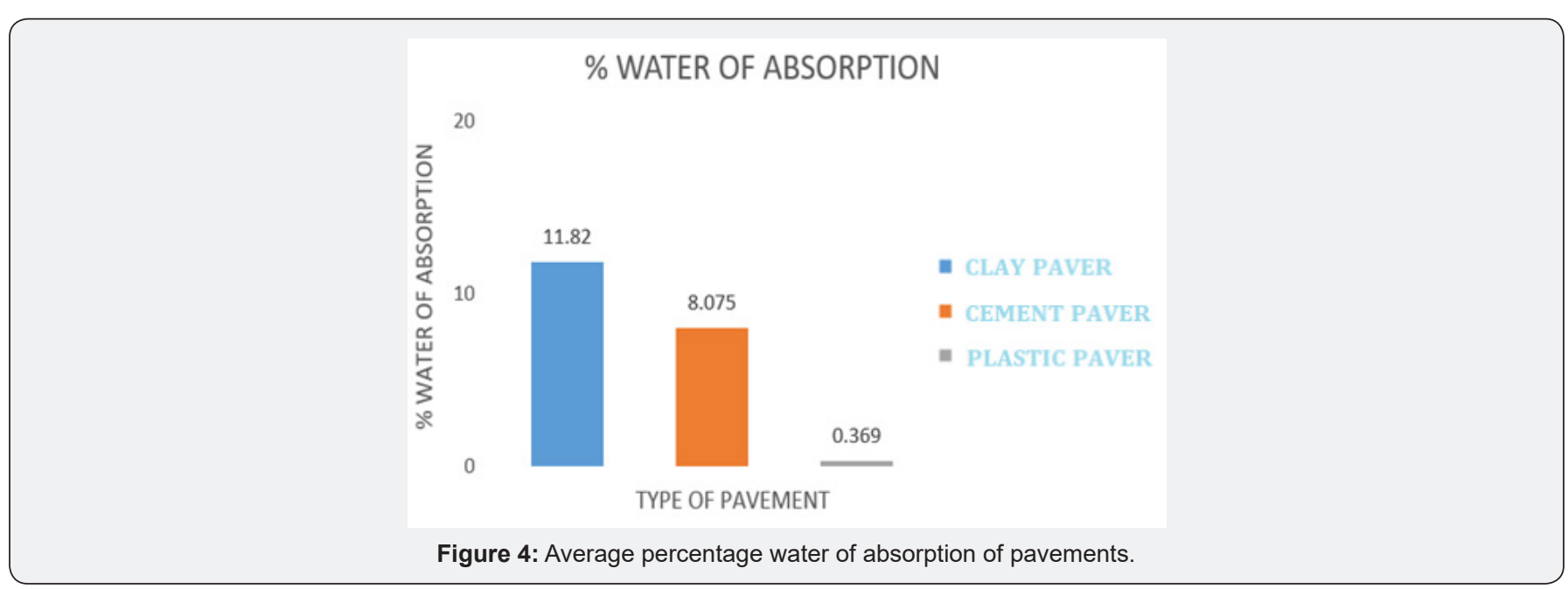




\section{Civil Engineering Research Journal}

\section{Abrasion Resistance}

Abrasive resistance is a measure of the resistance of paving brick to the wearing action due to traffic and can be calculated using equation (2).

Abrasive index $=$ (water absorption $)$ (compressive strength) $\times 100$
The maximum abrasion index for Type III i.e. pedestrian and light traffic pavement is 0.50 and the minimum abrasion limit for a 28day cured concrete paver is 1.20 for footpaths and car parks (ASTM C 902-15). The three types of pavers have abrasion index of $0.35,0.14$ and 0.014 for clay, cement and fired clay pavement blocks respectively Figure 5.

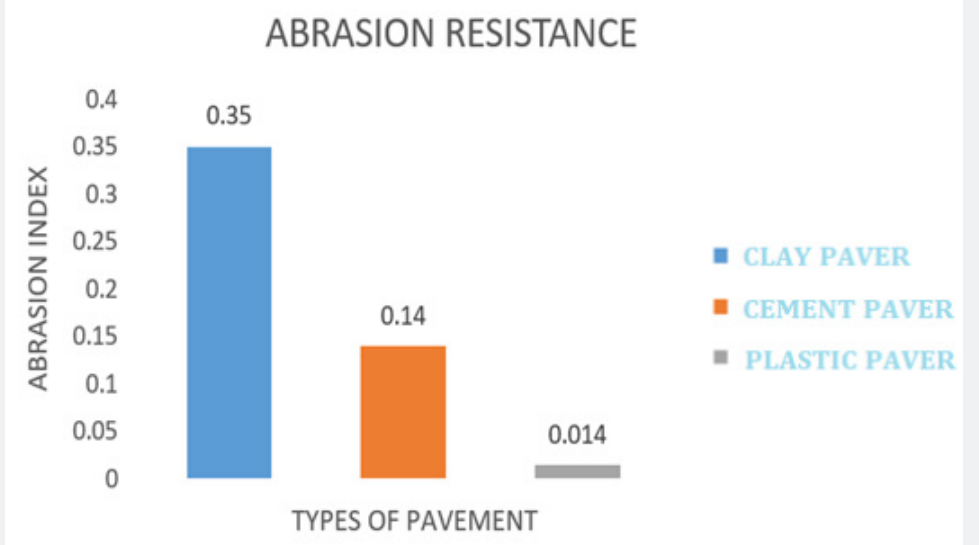

Figure 5: Calculated average abrasive index for the various pavers.

\section{Durability in Sea water}

Percentage of seawater absorbed by the three different pavement blocks are shown in Figure 6.

\section{Discussion}

The density of fired clay pavers has been stated to be between $1.826 \mathrm{~g} / \mathrm{cm}^{3}$ and $1.985 \mathrm{~g} / \mathrm{cm}^{3}$, and specific gravity of special masonry varies between $1.20 \mathrm{~g} / \mathrm{cm}^{3}$ and $2.40 \mathrm{~g} / \mathrm{cm}^{3}$ (ASTM C-902). From the results in Figure 1, Clay pavers had the minimum density value followed by the plastic and cement pavers of densities $2.04 \mathrm{~g} / \mathrm{cm}^{3}$ and $2.10 \mathrm{~g} / \mathrm{cm}^{3}$ respectively. The 3 types however fall within the standard specification. Clay pavement blocks recorded higher average compressive strength, followed by plastic pavement blocks and then cement pavement blocks. Clay pavement blocks have highest thickness compared to plastic and cement pavement blocks and this may have contributed to the high compressive strength. Also, the compressive strength of the plastic pavement blocks was not determined on full blocks but on a cut-out section, may have caused a reduction in the compressive strength of plastic pavement blocks as noted by Vila et al. [5]. The production of fired clay pavement blocks currently in Ghana relies on firewood and requires much energy during firing. Harmful gases such $\mathrm{CO}_{2}$ may also be released into the environment which is not eco-friendly. When firing is not well controlled, clay bricks can develop cracks which may lead to reduction in strength.

Cement pavers recorded the least compressive strength value as compared to the plastic pavers. Poor compaction is a major factor that influence the strength of cement pavers which creates more pores to absorb water. Secondly, decreased strength in concrete pavers can be attributed to variation in the mix proportions in the batching process. Improper mixing proportions and insufficient compaction hinders the achievement of maximum density and creates voids which contributes to reducing the strength of the concrete pavers. Increasing void content and decreasing density decreases the compressive of the concrete pavers [6]. Plastic pavers recorded higher compressive value than cement pavers. Melting of plastics for plastic pavers requires less energy since plastics have low melting points and melting is done at low temperatures. The melting process does not release harmful gases into the environment, and it is cheaper to produce. Therefore, plastic pavers may be used commercially for non-traffic application. The high flexural strength average value obtained for plastic modified pavement block as compared to the concrete pavers and fired clay pavers may be due to good adhesion of molten plastic to the sand particles and low porosity. This is an indication that the plastic pavement blocks could withstand higher flexural stresses than the rest

Results obtained for water of absorption indicated that fired clay pavers absorbed maximum water as compared to cement paver and plastic paver. The maximum water absorption by the fired clay pavers may have occurred as a result of the presence of pores and due to the hydrophilic nature of clay. Increased absorption of water may result in loss of bondage of clay particles hence reduced strength of clay pavement blocks in service. The cement pavers absorbed less water as compared to the fired clay pavers. This is because the cement creates stronger bonds between the particles, and this minimizes the pores through which water get absorbed by the concrete pavement block [7]. However average value obtained for both fired clay and cement pavement blocks are more than the minimum value of $5 \%$. Thus, the use of these 


\section{Civil Engineering Research Journal}

pavement blocks may not be durable especially in waterlogged areas. Water absorption values obtained for plastic pavers are within the specified standard of less than $5 \%$. This may be due the low porosity of the plastic pavers and due to the hydrophobic nature of plastics. The water of absorption of plastic pavers have been found to further decrease when the proportion of plastic waste is increased. The low porosity of the plastic pavers may contribute to little or no damage under severe conditions such as heavy rains as compared to fired clay paver and cement pavers. Fired clay paver and cement pavers may absorb water under severe condition, and this has a tendency of weakening the bonds that exist between their structures which may lead to formation of micro cracks. Hence any load applied on fired clay paver and cement pavers, may act on the stress concentration points because of the presence of micro cracks and this may cause decrease in strength. The very low abrasion resistance value recorded by the plastic pavers indicates that plastic pavers have high ability to withstand wearing action than clay bricks and cement pavers which may be as a result of the good adherence of the plastic with the sand aggregates. Seawater durability is the ability of pavers to resist permeability of saline solution and have improved strength to be serviceable. Four months durability in Sea water test results are shown in Figure 4 for the various types of pavers under study.

The permeability of sea water in pavers causes two main actions to occur; chemical reaction which usually occurs within the pavers resulting in softening and disruptive expansion of the pavement blocks, and crystallization of salts which occurs on the surface of the pavers. As pavers absorb sea water, the dissolved salts in the form of crystals are left within the joint and the pores of the pavers which may cause expansion and increases porosity thereby reducing the strength of pavers [8]. As indicated by results in Figure 6, plastic pavers absorbed less Sea water. This may be due to the low porosity exhibited and due to the structure of plastics, i.e. strong with close intermolecular links and so this type of pavers resists sea water [9-14] absorption as compared to the cement and clay pavers. Therefore, plastic pavers may remain stronger in terms of durability in high saline environment.

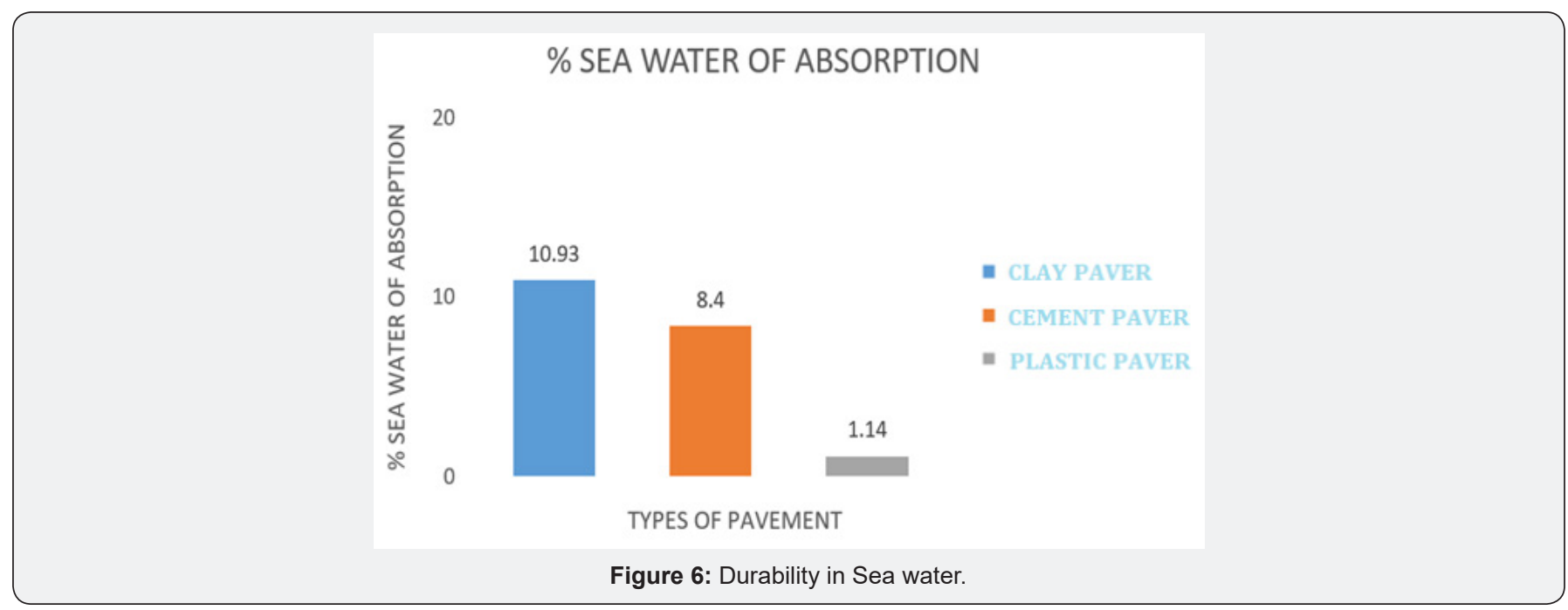

\section{Conclusion}

In this study clay pavement and plastic pavement blocks obtained higher average compressive strength than the cement pavement blocks. Durability studies suggested that plastic pavement blocks may perform better in areas prone to flooding and high saline content. Though the various pavement blocks may be used for footpath, light traffic, walkway etc., the plastic pavement blocks made from waste plastic and sand may be cheaper and represent an alternative way of turning waste material into useful product for a more sustained construction. Plastic waste use as transitional material in construction is a demonstration of how waste could be turned into a resource for cost effective, yet a durable and sustainable material for construction. Other advantages include minimizing plastic waste in the environment, the landfills and water bodies contributing to cleaner cities and towns and creation of more jobs.

\section{References}

1. Owusu-Sekyere E, Issaka KO, Abdul-Kadri Y (2013) An Analysis of the Plastic Waste Collection and Wealth Linkages in Ghana. International Journal of Current Research 5 (1): 205-209.

2. Gencel 0, Ozel C, Fuat Koksal F, Erdogmus E, Gonzalo Martínez-Barrera $G$ et al. (2012) Properties of concrete paving blocks made with waste marble. Journal of Cleaner Production. Elsevier Ltd 21 (1): 62-70.

3. Ling TC, Nor HM, Hainin MR, Lim SK (2010) Long-term strength of rubberised concrete paving blocks, Proceedings of the Institution of Civil Engineers - Construction Materials 163(1): 19-26.

4. Ling TC, Nor HM, Lim SK (2010) Using recycled waste tyres in concrete paving blocks, Proceedings of the Institution of Civil Engineers - Waste and Resource Management. ICE Virtual Library 163(1): 37-45.

5. Vila P, Pereyra MN, Gutiérret À (2017) Compressive strength in concrete paving blocks. Results leading to validate the test in half-unit specimens. Revista, ALCONPAT 7 (3): 247-261.

6. Dowson AJ (1980) Mix design for concrete block paving, Proceedings of the First International Conference on Concrete Block Paving, Newcastle-upon-Tyne, UK Pp. 121-127. 


\section{Civil Engineering Research Journal}

7. Quezon ET, Kebede G (2017) Comparative Study on Compressive Strength of Locally Produced Fired Clay Bricks and Stabilized Clay Bricks with Cement and Lime.

8. Visser AT (2003) Durability of Block Paving In a marine Environment. Proceedings of the $7^{\text {th }}$ International Conference on Concrete Block Paving. (PAVE AFRICA 2003) Sun City South Africa Pp: 1-8.

9. (2015) ASTMC902-15 Standard Specification for pedestrian and light Traffic Paving Brick. ASTM International West Conshohocken.

10. Bureau of Indian Standards IS 15658 (2006) Precast Concrete blocks for paving.

11. Karaman S, Ersahin S, Gunal H (2006) Firing temperature and firing time influence on mechanical and physical properties of clay bricks. Journal of Scientific and Industrial Research 65(2): 153-159.
12. Muñoz Velasco P, Morales MP, Mendivil Giro MA, Muñoz Velasco L (2014) Fired clay bricks manufactured by adding wastes as sustainable construction material- A review. Construction and Building Materials 63: 97-107.

13. Njoya D, Tadjuidje FS, Ndzana EJ, Pountouonchi A, Tessier-Doyen N et al.(2017) Effect of flux content and heating rate on the microstructure and technological properties of Mayouom (Western-Cameroon) kaolinite claybased ceramics. Journal of Asian Ceramic Societies. Taibah University 5(4): 422-426.

14. Vasudevan R, Ramalinga Chandra Sekar A, Sundarakannan B, Velkennedy R (2011) A technique to dispose waste plastics in an ecofriendly way - Application in construction of flexible pavements. Construction and Building Materials, Elsevier Ltd 28(1): 311-320.

\section{Your next submission with Juniper Publishers will reach you the below assets}

- Quality Editorial service

- Swift Peer Review

- Reprints availability

- E-prints Service

- Manuscript Podcast for convenient understanding

- Global attainment for your research

- Manuscript accessibility in different formats

( Pdf, E-pub, Full Text, Audio)

- Unceasing customer service

Track the below URL for one-step submission https://juniperpublishers.com/online-submission.php 